A A compelling counfer-project against - neoliberalisig restoring the collective foundations of everyday life?

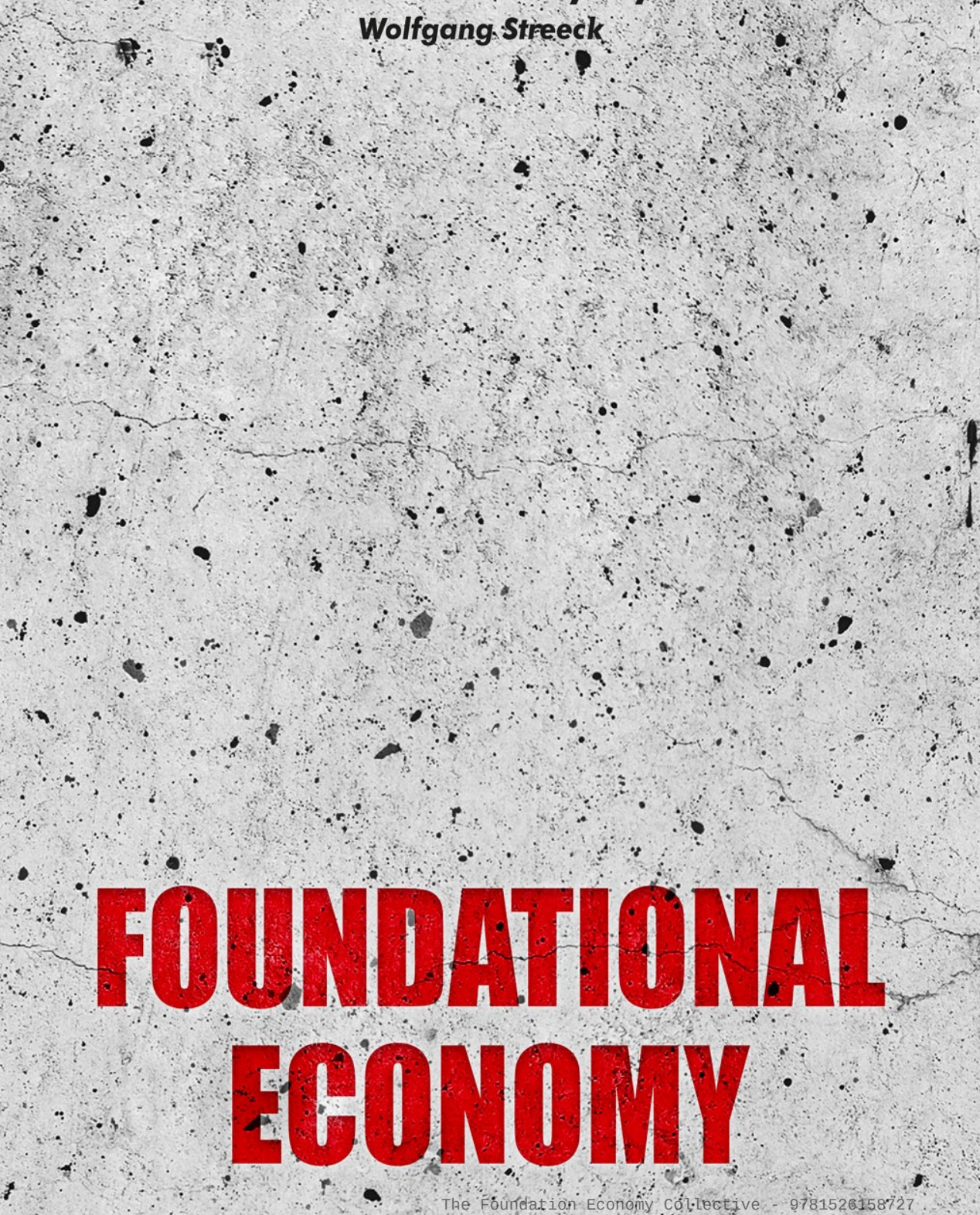

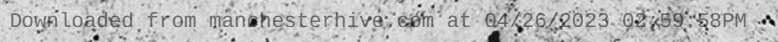




\section{Foundational economy}

\section{MANCHESTER 1824}

Manchester University Press 


\section{The Manchester Capitalism book series}

\section{GENERAL EDITORS: JULIE FROUD AND KAREL WILLIAMS}

Manchester Capitalism is a series of books which follows the trail of money and power across the systems of our failing capitalism. The books make powerful interventions about who gets what and why in a research based and solidly argued way that is accessible for the concerned citizen. They go beyond critique of neo liberalism and its satellite knowledges to re-frame our problems and offer solutions about what is to be done.

Manchester was the city of Engels and Free Trade where the twin philosophies of collectivism and free market liberalism were elaborated. It is now the home of this venture in radical thinking that challenges self-serving elites. We see the provincial radicalism rooted here as the ideal place from which to cast a cold light on the big issues of economic renewal, financial reform and political mobilisation.

Already published:

The end of the experiment: From competition to the foundational economy

What a waste: Outsourcing and how it goes wrong

Licensed larceny: Infrastructure, financial extraction and the global South

The econocracy: The perils of leaving economics to the experts

Reckless opportunists: Elites at the end of the establishment

Forthcoming:

Safe as houses: Private greed, political negligence and housing policy after Grenfell

Systems city: A new politics of provision for an urbanized planet 


\section{Praise for Foundational Economy}

'A compelling counter-project against neoliberalism: restoring the collective foundations of everyday life'

Wolfgang Streeck, Max Planck Institute for the Study of Societies, Germany

'This is an interesting and important contribution to the economic debates going on today. It underlines the centrality of collectivism and universalism as pillars of a decent society, as well as asking searching questions about the kind of solutions we need to the economic problems of our age.'

John McDonnell, Shadow Chancellor of the Exchequer

'Something has gone very wrong with the British economy. Investment and growth is poor and the proceeds are not fairly shared. Pay is unequal and stagnating for the majority. Too many people are trapped in insecure, low-paid and zero hours work. Outsourcing giants make a killing extracting value from our public services. And affordable housing remains a distant dream, especially for young families. This is the everyday reality that working people face and Foundational Economy sets out a razor sharp analysis of the reasons why. But, more importantly, it delivers practical proposals for change. A smart and dynamic state at a national and local level, democratisation of our communities and workplaces, investment in public services - and those parts of our economy that most people depend on and where most people earn their living. This agenda poses big challenges for policy makers, politicians and civil society alike. But they must be met if we are to have an intelligent industrial policy for economic justice and twenty-first-century public services that meet the needs of every community across the UK. Doing more of the same is not an option. Foundational Economy provides a springboard for the new deal working people need.'

Frances O’Grady, General Secretary, Trades Union Congress 
'An essential attempt to transform how we think about economics, a searing critique of where we've gone wrong, and a powerful call for a renewed "provincial radicalism". This is a key contribution towards building a more equal and democratic economy and to reconnecting economics and politics with the everyday lives of communities across Britain.'

Rachel Reeves MP, Labour Party politician, economist and chair of the Business, Energy and Industrial Strategy Committee

'This fascinating book, Foundational Economy, can be seen as a contribution to the debate about measuring, understanding and, ultimately, reshaping economic systems. More than that, it is a critique of existing custom and practice when measuring, understanding and shaping the economy. This critique is as foundational as the book's title. We are some way short of a well-defined and widely-agreed set of new weights and measures for the economy. And we are a long way short of knowing which policy tools best deliver the private and collective goods society needs to flourish. This book tackles head-on some of those big questions about the economy. It also begins the process of providing answers. As in the natural sciences, as an approach I think this offers hope for societal, as well as scientific, advance.'

Andy Haldane, Chief Economist, Bank of England

'There is now a widespread and growing view that the UK economy has ceased to work effectively for ordinary people. This original and challenging book sets out a compelling argument for why this is happening. You do not have to sign up to every individual point made in the book to recognise the power of the overall argument. At the heart of the book is the idea of the 'foundational economy', its rise in the municipal era, its fall in the neo-liberal era and how it might be renewed again. The term foundational may not be in everyday use but what it describes represents the essential fabric of our lives - the essential infrastructure of energy, water and transport, and the essential services of education, 
health and care. These are distinguished by being essentially collective goods. They cannot simply be 'bought' by an individual but must be decided by society as a whole. For the last 30 or so years, it has been the accepted wisdom of many politicians and policy makers that these services are best enabled publicly but delivered privately. The book provides a robust challenge to this view. Those looking to find individual policy solutions in this book will be disappointed. It is much more about changing the way we think about economics and society. But is does contain a message of hope in some pretty challenging times. Recommended reading lists for civil servants are quite a common occurrence at Christmas time. This book deserves to be on those lists.'

Lord Bob Kerslake, Head of the UK Civil Service, 2011-14

'For decades economic policy has been done to people and not with and by them. It has not for the most part focused on the sectors of the economy that matter to people every day or on the communities that most need to benefit. The foundational economy approach represents a move away from grand industrial projects and the unaccountable power of neo-classical economics. In a world of falling living standards, wellbeing in reverse gear, enormous wealth inequality and urgent environmental crises, it is an approach whose time has come.'

Andrew Pendleton, Director of Policy and Advocacy at the New Economics Foundation

'In the honourable tradition of provincial radicalism, the Foundational Economy Collective open new horizons for social, economic and political renewal with their provocative and yet practical proposals for reconstructing everyday economies. This is not the time for incremental tinkering with the status quo, nor critique solely for its own sake. Instead, Foundational Economy delivers an arresting and imaginative manifesto for rebuilding our communities from the ground up. Founded on a political economy of hope, not despair, this approach is 
radical in all of the best senses of the word: it cuts to the root of wicked problems, rethinking from first principles; it steadfastly refuses to be cowed or constrained by stale orthodoxies; and it illuminates an alternative pathway, guided by the principles of inclusive citizenship, social innovation, ethical investment, and progressive political renewal. This is a book that is sure to change some minds, and maybe even the future.' Jamie Peck, University of British Columbia, Canada

'Read this book if you want to understand why the NHS is not funded through taxes raised from the private sector; if you want to know why our children will not be mostly employed in 'high tech' industry in future (and cannot be); why the welfare state was a good protection racket; why British privatised rail companies lie so much about their 'greatness'; why care homes are so badly run at such great private profit by 'entrepreneurs'; and how those who rob us so often claim a defence of 'diminished responsibility' for their acts of great harm. All that is in just the first two chapters of Foundational Economy. The collective that produced this book of wonders deserves to be warmly congratulated on producing such a clear explanation of, amongst so much else, how "the British and Americans led the way to a new kind of rentier capitalism." And what now to do about it - in a way that cannot be as easily extinguished as radical politics in the recent past has been.'

Danny Dorling, University of Oxford

'A dedicated group of scholars across a broad range of disciplines at Manchester University have long led the way in detailing and analysing what the late Michael Moran, one of the foremost among them, identified as the "financial services revolution" at the root of the transformation of public policy into the handmaiden of privatisation and marketisation. This new book, perfectly timed to coincide with the growing populist disgust with what they call "a generation of failure to make 
the market work", concentrates on penetrating the fog currently generated by all the talk across the political spectrum about the importance of investment in infrastructure. Brilliantly conceiving and concisely explaining in historical and comparative perspective the social and moral basis of "foundational" goods and services, this book is essential reading for all concerned to escape the predations of financial engineering and bring the "everyday infrastructure of civilised life" into the public domain under democratic control.'

Leo Panitch, York University, Canada and editor of The Socialist Register

'Citizens have rights to basic services because their public provision underpins capacities and capabilities for all. This inspirational reformulation of the Foundational Economy explains why we need to stop wrecking our public services in Europe and start refashioning their future in the twenty-first century. It is not enough to claim that the Foundation Economy is a moral enterprise and the authors lay out new directions for social innovation enabling us to reinvent both our political practice and the world we hope for.'

Henrietta L. Moore, Director of the UCL Global Prosperity Institute

'Foundational Economy outlines the need for collective provision of the essential services which are the social infrastructure of everyday life. Its arguments and strategies are a vital contribution to the debate across Europe about renewing progressive economic policies. The book provides meticulous historical evidence as to the way collective provision was eroded under neoliberalism, and evidence-based ideas for what states, collectives and individuals can do. It is a major contribution to the debate about how we can actively shape our post capitalist future.'

Paul Mason, journalist and author of PostCapitalism: A Guide to Our Future 
'So much of the writing since the crash has been glib optimism, smartly-packaged gobbets of wishful thinking. This book is nothing of the sort. It is a draught of cold realism. Britain isn't going back to some mythical golden age nor will it catapult into some jetpack future, so it's time to face ugly facts and think harder about how to create the society and economy we want. The authors are engaged academics and they bring analytical hard-headedness, a fresh political imagination - and a welcome outsider chippiness. This is the kind of economics that never makes it onto the City pages, the sort of politics that rarely gets into newspaper columns. Read it.'

Aditya Chakrabortty, Senior Economics Commentator, The Guardian

'The rise in economic, social and recognition inequalities and the correlated authoritarian dynamic are not the result of unavoidable system changes, but of policy choices and a change in both the balance of power and common sense. The research team which has launched the Foundational Economy project now addresses these issues by forcefully outlining a reversal of policymaking so that citizen's capabilities, substantive freedom and social consumption regain centre stage. A welcome contribution to the urgent rethinking of economics and politics.'

Fabrizio Barca, previously Divisional Head of Research at the Bank of Italy, special adviser to the EU Commissioner responsible for regional policy and Italian Minister of Territorial Cohesion (2011-13)

'Since 1988, Barcelona has developed five strategic plans, all of them having "business friendly" postulates as their basis. When a year ago the new team in charge of the future metropolitan strategy decided to place five basic elements for life (air, water, food, energy and housing) as the core elements for that strategy, we did not know a word about the proposal of the Foundational Economy. Now that we have had the opportunity to read this inspiring book, we not only consider 
our vision strengthened, but we also have the elements to more solidly support it and even reinforce it, incorporating some of the valuable insights that the authors provide. A must-read for all of us who are committed to improve wellbeing in our cities and our society in general.'

Oriol Estela Barnet, General Co-ordinator of PEMB, The Office for Strategic Planning of the City and Metropolitan Area of Barcelona; previously Head of the Office for Local Economic Development (2012-16)

'In this book the authors present an innovative and creative account of economic development, one driven by the need to preserve our "Foundational Economy" in Europe. To do this the authors convincingly make the case that Europe's foundational economy is a significant driver of social not simply individual market driven consumption. The distinctive primary role of public policy is about how experimentation, at a local level, can be directed to help secure the continuity of basic foundational services upon which Europe's citizens depend and need to flourish.'

Theodor Dumitru Stolojan, European People's Party group (Christian Democrats), Chairman of the IFRS Permanente team of the European Parliament, previously Prime Minister of Romania 1991-92 and presidential candidate 2000 and 2004)

'In Foundational Economy we are presented with an alternative and refreshing view of social policy. The innovative argument presented by this Europe-wide collective group of authors is that the primary role of public policy should be re-aligned towards promoting the 'Foundational Economy'. These foundational activities are often overlooked and, to a significant extent, taken for granted. But they should not be overlooked because these activities generate social consumption upon which all citizens across Europe depend for our collective welfare, household employment and general well-being.' Eva Kaili MEP, Group of the Progressive Alliance of Socialists and Democrats in the European Parliament 
The Foundation Economy Collective - 9781526158727 Downloaded from manchesterhive.com at $04 / 26 / 2023$ 02:59:58PM 


\section{Foundational economy}

\section{The infrastructure of everyday life}

\section{Foundational Economy Collective}

Davide Arcidiacono, Filippo Barbera, Andrew Bowman, John Buchanan, Sandro Busso, Joselle Dagnes, Joe Earle, Ewald Engelen, Peter Folkman, Julie Froud, Colin Haslam, Sukhdev Johal, Ian Rees Jones, Dario Minervini, Mick Moran, Fabio Mostaccio, Gabriella Pauli, Leonhard Plank, Angelo Salento, Ferdinando Spina, Nick Tsitsianis, Karel Williams

Manchester University Press 
Copyright () Julie Froud, Sukhdev Johal, Michael Moran, Angelo Salento and Karel Williams 2018

The right of Julie Froud, Sukhdev Johal, Michael Moran, Angelo Salento and Karel Williams to be identified as the authors of this work has been asserted by them in accordance with the Copyright, Designs and Patents Act 1988.

Published by Manchester University Press

Altrincham Street, Manchester M1 7JA

www.manchesteruniversitypress.co.uk

British Library Cataloguing-in-Publication Data

A catalogue record for this book is available from the British Library

ISBN 9781526133991 hardback

ISBN 9781526134004 paperback

First published 2018

The publisher has no responsibility for the persistence or accuracy of URLs for any external or third-party internet websites referred to in this book, and does not guarantee that any content on such websites is, or will remain, accurate or appropriate.

Typeset

by Toppan Best-set Premedia Limited 